\title{
Effect of renal transplantation on marrow mast cell hyperplasia of chronic renal failure
}

\author{
H. A. Ellis ${ }^{1}$, KAThleEN M. PEART ${ }^{1}$, AND A. M. PIERIDES 2 \\ From the Departments of Pathology 1 and Medicine ${ }^{2}$, University of Newcastle upon Tyne, UK
}

SUMMARY Marrow mast cells have been counted in iliac bone from patients with chronic renal failure treated by renal transplantation. Mast cell numbers were initially increased but returned to the normal range in many patients after renal transplantation. Improvement in osteitis fibrosa and osteomalacia after transplant was not clearly related to this diminution in the number of mast cells. The use of prednisone in renal transplant patients may have some effect in reducing the numbers of mast cells. There is no fully acceptable explanation for the increase in marrow mast cells which occurs in chronic renal failure.

In previous papers we reported that there is an increase in the number of iliac bone marrow mast cells in chronic renal failure (Peart and Ellis, 1975) and that this marrow abnormality persists in spite of treatment by haemodialysis (Ellis and Peart, 1976). There was a tendency towards a greater number of mast cells in patients with more severe degrees of osteitis fibrosa, but we were unable consistently to relate hyperparathyroidism to marrow mast cell hyperplasia. There was no definite causal relationship between the presence or severity of osteomalacia and the number of marrow mast cells in patients with renal disease. Haemodialysis brings about a fluctuating improvement in the various changes of chronic renal failure and we therefore wished to determine the effect successful renal transplantation might have on the number of marrow mast cells when renal function improves and there is healing of osteomalacia and resolution of osteitis fibrosa (Pierides et al., 1975).

In the present paper we report the results of observations made on the numbers of marrow mast cells in iliac bone biopsies obtained from patients before and after renal transplantation and attempt to relate the changes in mast cell numbers to improvement in renal function, osteomalacia and osteitis fibrosa, and to the administration of prednisone.

\section{Material and methods}

BONE

Details of the techniques for the processing of iliac

Received for publication 23 March 1977 bone, point-counting of bone, assessment of osteitis fibrosa and osteomalacia, and the counting of mast cells have been given previously (Ellis and Peart, 1972, 1973; Peart and Ellis, 1975; Ellis and Peart, 1976).

\section{PATIENTS}

Sixty-five post-transplant iliac bone samples were examined from 47 patients. The samples were generally obtained by transiliac bone biopsy. A few were necropsy samples. Samples fall into three main groups with regard to time after renal transplantation: 37 at $8-15$ months, 22 at $20-27$ months, and 6 at $>36$ months. In 35 of the patients pre-renal transplant iliac bone biopsies were also studied.

\section{Results}

The data for individual patients are summarised in Table 1. The pre-transplant mast cell values are significantly increased compared with controls (Mann-Whitney test for non-parametric data), whether pre-transplant biopsies are considered together or in groups, depending upon the time before transplantation (Table 2). The increase is of the same order as that previously observed in patients with chronic renal failure (Table 2).

There is a significant fall in mast cell numbers when a comparison is made between all pretransplant and all post-transplant bone samples (Table 2). In some patients the number of mast cells decreased but did not return to normal and the post-transplant mast cell numbers are still significantly increased in comparison with the controls 
Table 1 Details of numbers of marrow mast cells before and after renal transplantation with summary of the duration of haemodialysis, timing of bone samples, and bone histology

\begin{tabular}{|c|c|c|c|c|c|c|c|c|c|c|c|c|c|c|c|c|}
\hline \multirow[t]{3}{*}{ Case } & \multicolumn{5}{|c|}{ Pre-renal transplant } & \multicolumn{11}{|c|}{ Post-renal transplant } \\
\hline & \multicolumn{2}{|c|}{ Timing of bone sample } & \multirow{2}{*}{$\begin{array}{l}\text { Number of } \\
\text { marrow } \\
\text { mast cells } \\
\text { per } \mathrm{mm}^{2}\end{array}$} & \multirow{2}{*}{\multicolumn{2}{|c|}{$\begin{array}{l}\text { Bone } \\
\text { histology }\end{array}$}} & \multicolumn{4}{|l|}{ 8-15 months } & \multicolumn{4}{|c|}{ 20-27 months } & \multicolumn{3}{|c|}{$>36$ months } \\
\hline & $\begin{array}{l}\text { Duration } \\
\text { of haemo- } \\
\text { dialysis } \\
\text { (months) }\end{array}$ & $\begin{array}{l}\text { Time } \\
\text { relative to } \\
\text { date of } \\
\text { transplant }\end{array}$ & & & & $\begin{array}{l}\text { Time after } \\
\text { transplant } \\
\text { (months) }\end{array}$ & $\begin{array}{l}\text { Number of } \\
\text { marrow } \\
\text { mast cells } \\
\text { per } \text { mm }^{2}\end{array}$ & Bisto & $e^{e} \log y$ & $\begin{array}{l}\text { Time after } \\
\text { transplant } \\
\text { (months) }\end{array}$ & $\begin{array}{l}\text { Number of } \\
\text { marrow } \\
\text { mast cells } \\
\text { per } \mathrm{mm}^{2}\end{array}$ & $\begin{array}{l}\text { Bone } \\
\text { histo }\end{array}$ & $\begin{array}{l}e \\
\text { ology }\end{array}$ & $\begin{array}{l}\text { Time after } \\
\text { transplant }\end{array}$ & $\begin{array}{l}\text { Number of } \\
\text { marrow } \\
\text { mast cells } \\
\text { per } \mathrm{mm}^{2}\end{array}$ & $\begin{array}{l}\text { Bone } \\
\text { histology }\end{array}$ \\
\hline 1 & 35 & $D$ of $T$ & $4 \cdot 54$ & $\mathbf{M}$ & F2 & - & - & - & & - & - & - & & $5 \mathrm{yr}$ & $4 \cdot 38$ & $\mathbf{N}$ \\
\hline 2 & 10 & $D$ of $T$ & $49 \cdot 12$ & $\mathbf{M}$ & F3 & - & - & - & & - & - & - & & $5 \mathrm{yr}$ & $12 \cdot 15$ & $\mathbf{N}$ \\
\hline 3 & 21 & $D$ of $T$ & $15 \cdot 15$ & $\mathbf{M}$ & F1 & - & - & - & & 24 & 0.52 & $\mathbf{M}$ & F1 & - & - & - \\
\hline 4 & 36 & $D$ of $T$ & 8.05 & $\mathbf{M}$ & Fi & 12 & 0.27 & & F1.5 & - & - & - & & - & - & - \\
\hline 5 & 39 & $D$ of $T$ & $18 \cdot 37$ & $\mathbf{M}$ & F1 & 12 & $8 \cdot 30$ & & F1.5 & 24 & $7 \cdot 34$ & $\mathbf{N}$ & & - & - & - \\
\hline 6 & 41 & $-1 \mathrm{mth}$ & $28 \cdot 74$ & $\mathbf{M}$ & F2.5 & 12 & $2 \cdot 41$ & & F2 & 24 & 3.89 & $\mathbf{N}$ & & - & - & - \\
\hline 7 & 42 & $D$ of $T$ & $89 \cdot 48$ & $\mathbf{M}$ & F1.5 & 12 & $59 \cdot 71$ & & F1 & 24 & $33 \cdot 32$ & $\mathbf{N}$ & & - & - & - \\
\hline 8 & 18 & $-1 \mathrm{mth}$ & 7.69 & $\mathbf{M}$ & & 12 & $1 \cdot 71$ & & F1 & 25 & 6.65 & $\mathbf{N}$ & & - & - & - \\
\hline 9 & 12 & $-1 \mathrm{mth}$ & $8 \cdot 23$ & $\mathbf{M}$ & F2 & 12 & 0.80 & $\mathbf{N}$ & & 24 & $3 \cdot 10$ & $\mathbf{N}$ & & - & - & - \\
\hline 10 & 6 & $-1 \mathrm{mth}$ & $5 \cdot 81$ & $\mathbf{M}$ & F1 & 12 & $12 \cdot 48$ & $\mathbf{N}$ & & 24 & $1 \cdot 76$ & $\mathbf{N}$ & & - & - & - \\
\hline 11 & 18 & $-18 \mathrm{mth}$ & $9 \cdot 16$ & $\mathbf{M}$ & F2.5 & 12 & $36 \cdot 12$ & & F1 & - & - & - & & - & - & - \\
\hline 12 & 84 & $\mathrm{D}$ of $\mathrm{T}$ & $92 \cdot 13$ & $\mathbf{M}$ & F1.5 & 12 & $16 \cdot 67$ & $\mathbf{N}$ & & - & - & - & & - & - & - \\
\hline 13 & 18 & $\mathrm{D}$ of $\mathrm{T}$ & $42 \cdot 91$ & $\mathbf{M}$ & & 12 & $4 \cdot 22$ & $\mathbf{N}$ & & - & - & - & & - & - & - \\
\hline 14 & 10 & $-10 d y$ & $59 \cdot 36$ & $\mathbf{M}$ & F1.5 & 12 & 2.01 & $\mathbf{N}$ & & - & - & - & & - & - & - \\
\hline 15 & 11 & $\mathrm{D}$ of $\mathrm{T}$ & $48 \cdot 18$ & $\mathbf{M}$ & F1.5 & 12 & 10.07 & & F1 & - & - & - & & - & - & - \\
\hline 16 & 30 & $-5 \mathrm{mth}$ & 6.58 & $\mathbf{M}$ & F1 & 12 & 2.61 & $\mathbf{N}$ & & - & - & - & & - & - & - \\
\hline 17 & 25 & $-3 \mathrm{mth}$ & $22 \cdot 36$ & $\mathbf{M}$ & & 12 & $2 \cdot 46$ & $\mathbf{N}$ & & - & - & - & & - & - & - \\
\hline 18 & 22 & $\mathrm{D}$ of $\mathrm{T}$ & $53 \cdot 25$ & $\mathbf{M}$ & F1 & 8 & 2.74 & $\mathbf{M}$ & F2 & - & - & - & & - & - & - \\
\hline 19 & 2 & $D$ of $T$ & 1.53 & $\mathbf{M}$ & F2 & 12 & 0.60 & & F1.5 & 20 & $4 \cdot 18$ & $\mathbf{M}$ & F1.5 & - & - & - \\
\hline 20 & 21 & $-6 \mathrm{mth}$ & $4 \cdot 17$ & $\mathbf{M}$ & F2 & 12 & $7 \cdot 37$ & & F1 & - & - & - & & - & - & - \\
\hline 21 & 14 & $-12 \mathrm{mth}$ & $8 \cdot 65$ & $\mathbf{M}$ & F1 & 15 & 0.55 & $\mathbf{N}$ & & - & - & - & & - & - & - \\
\hline 22 & 7 & $-3 \mathrm{mth}$ & 22.02 & $\mathbf{x}$ & F1 & - & - & - & & 24 & $9 \cdot 88$ & $\mathbf{M}$ & F1 & $36 \mathrm{mth}$ & 6.68 & $\mathbf{M}$ \\
\hline 23 & - & - & - & - & & 13 & $23 \cdot 54$ & $\mathbf{N}$ & & 24 & $25 \cdot 10$ & $\mathbf{N}$ & & & - & - \\
\hline 24 & - & - & - & - & & 13 & $2 \cdot 89$ & & F1.5 & 24 & 2.57 & $\mathbf{N}$ & & 39 mth & 14.08 & $\mathbf{N}$ \\
\hline 25 & - & - & - & - & & - & - & - & & 27 & 4.09 & & F2 & - & - & - \\
\hline 26 & 1 & $-2 \mathrm{mth}$ & 0.41 & & F1 & 12 & 0.29 & $\mathbf{N}$ & & 24 & $5 \cdot 42$ & $\mathbf{N}$ & & - & - & - \\
\hline 27 & 6 & $-4 \mathrm{mth}$ & $10 \cdot 43$ & $\mathbf{N}$ & & 12 & 4.99 & $\mathbf{N}$ & & 24 & 6.94 & $\mathbf{N}$ & & - & - & - \\
\hline 28 & 72 & $\mathbf{D}$ of $\mathbf{T}$ & $58 \cdot 50$ & & F4 & 12 & $17 \cdot 00$ & $\mathbf{N}$ & & - & - & - & & - & - & - \\
\hline 29 & - & - & - & - & & - & - & - & & 24 & $2 \cdot 35$ & & F1.5 & $40 \mathrm{mth}$ & $2 \cdot 88$ & F1 \\
\hline 30 & - & - & - & - & & - & - & - & & - & - & - & & $38 \mathrm{mth}$ & $16 \cdot 61$ & $\mathbf{N}$ \\
\hline 31 & 50 & $D$ of $T$ & $7 \cdot 79$ & & F2 & 12 & 0.87 & & F2.5 & 24 & $1 \cdot 46$ & & F1.5 & - & - & 一 \\
\hline 32 & 10 & $\mathrm{D}$ of $\mathrm{T}$ & $2 \cdot 81$ & $\mathbf{N}$ & & 12 & $0 \cdot 18$ & $\mathbf{N}$ & & 24 & 0.62 & $\mathbf{N}$ & & - & - & - \\
\hline 33 & 0 & $-2 \mathrm{mth}$ & $8 \cdot 78$ & & F1 & 12 & 0.94 & $\mathbf{N}$ & & 24 & 5.54 & $\mathbf{N}$ & & - & - & - \\
\hline 34 & 35 & $D$ of $T$ & 6.29 & $\mathbf{N}$ & & 12 & $3 \cdot 26$ & $\mathbf{N}$ & & - & - & - & & - & - & - \\
\hline 35 & 27 & $-2 \mathrm{mth}$ & $4 \cdot 86$ & & F2 & 12 & $2 \cdot 26$ & $\mathbf{N}$ & & 26 & $19 \cdot 23$ & $\mathbf{N}$ & & - & - & - \\
\hline 36 & - & - & - & - & & - & - & - & & 24 & 1.26 & & F1 & - & - & - \\
\hline 37 & - & - & - & - & & - & - & - & & 24 & 1.07 & $\mathbf{N}$ & & - & - & - \\
\hline 38 & - & - & - & 一 & & 13 & $19 \cdot 28$ & $\mathbf{N}$ & & - & - & - & & - & - & - \\
\hline 39 & 16 & $-4 \mathrm{mtb}$ & $26 \cdot 37$ & & F1.5 & 12 & $5 \cdot 43$ & $\mathbf{N}$ & & - & - & - & & - & - & - \\
\hline 40 & 0 & $-1 \mathrm{mth}$ & $21 \cdot 42$ & $\mathbf{N}$ & & 12 & 3.09 & $\mathbf{N}$ & & - & - & - & & - & - & - \\
\hline 41 & 2 & $D$ of $T$ & $3 \cdot 85$ & & F1.5 & 12 & 0.92 & $\mathbf{M}$ & F1.5 & - & - & - & & - & - & - \\
\hline 42 & - & - & - & - & & 12 & $28 \cdot 40$ & $\mathbf{N}$ & & 一 & - & - & & - & - & - \\
\hline 43 & $\mathbf{0}$ & $-5 \mathrm{mth}$ & $24 \cdot 44$ & $\mathbf{N}$ & & 12 & $5 \cdot 83$ & $\mathbf{N}$ & & - & - & - & & - & - & - \\
\hline 44 & - & - & - & - & & 12 & $8 \cdot 48$ & $\mathbf{N}$ & & - & - & - & & - & - & - \\
\hline 45 & 2 & $D$ of $T$ & 22.94 & $\mathbf{N}$ & & 12 & 3.96 & $\mathbf{N}$ & & - & - & - & & - & - & - \\
\hline 46 & - & - & - & - & & 12 & 2.65 & $\mathbf{M}$ & F2 & - & - & - & & - & - & - \\
\hline 47 & - & - & - & - & & - & 一 & - & & 25 & 0.43 & $\mathbf{N}$ & & - & - & - \\
\hline
\end{tabular}

D of T, day of transplant; N, no osteomalacia, no osteitis fibrosa; M, osteomalacia, no osteitis fibrosa; F, osteitis fibrosa, no osteomalacia; MF, osteomalacia and osteitis fibrosa. Numerals after $F$ refer to severity of osteitis fibrosa on scale 1-5. $X$, no undecalcified section available.

(Table 2). There is a significant reduction in the numbers of mast cells in bone samples at both 8-15 months and 20-27 months after renal transplantation but at $>36$ months there is no significant difference. There are few cases in this last category, and in three, for which serial biopsies were available, there had been a reduction in mast cell numbers in two and no change in the third. However, in one patient there was an increase in the number of mast cells at 39 months compared with values at 13 and 24 months.
There is no significant difference between the numbers of mast cells at 8-15 months and at 20-27 months after renal transplant (Table 2).

In those patients with serial pre- and posttransplant bone samples there is a significant reduction in the number of mast cells at both 8-15 months and 20-27 months, but the fall is of a lower order of significance for the second period (Table 3 ). In comparison with pre-transplant values, there is a reduction in mast cell numbers at 8-15 months in 
Table 2 Summary and comparison of marrow mast cell numbers in patients before and after renal transplantation

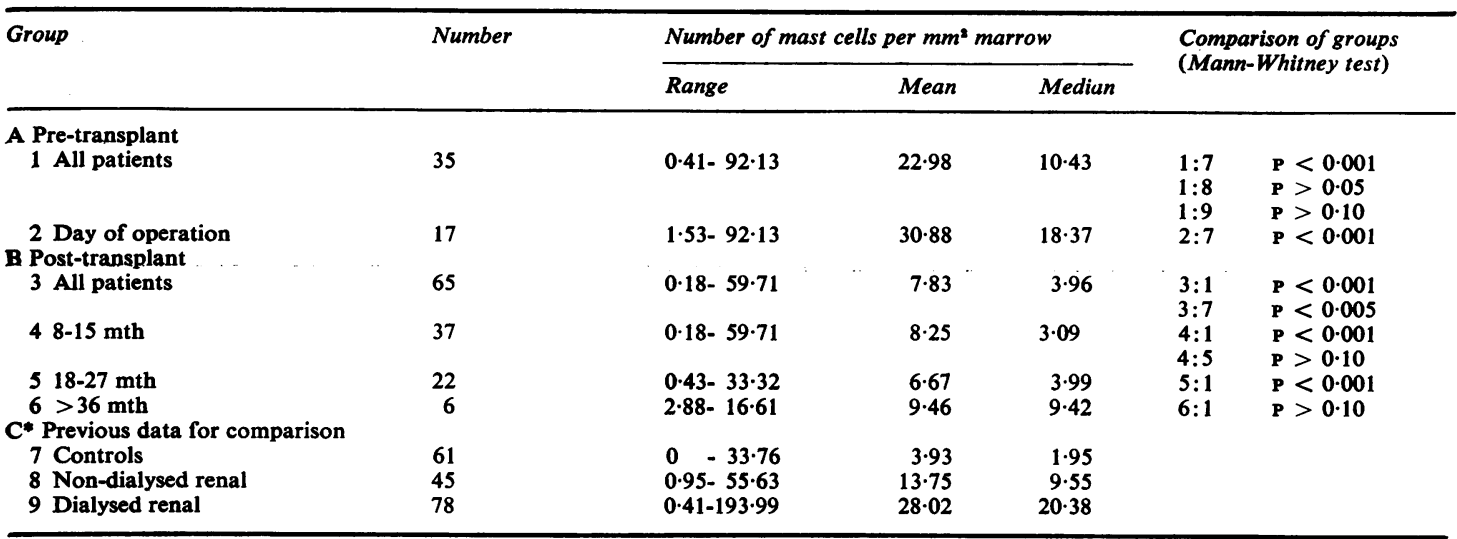

*Sze Peart and Ellis (1975) and Ellis and Peart (1976).

28 out of 31 patients, and this is also the case at 20-27 months in 12 out of 15 patients. However, comparison of these two post-transplant groups shows that there has been a further fall in mast cell numbers in only 4 out of 15 patients and in 11 there has been an increase (Table 3).

\section{RELATIONSHIP BETWEEN CHANGES IN} NUMBERS OF MAST CELLS AND IMPROVEMENT OF OSTEOMALACIA

Undecalcified sections were available before renal transplantation in 34 of the 35 patients. There was some degree of osteomalacia in $21(61.8 \%)$ but in three of these it was borderline or minimal. Although some of the highest mast cell values were obtained in patients with osteomalacia (Figure; Table 1), a comparison of the numbers of mast cells in 18 patients with moderate to severe osteomalacia with those in 13 patients without osteomalacia reveals no significant difference (Mann-Whitney test, $z=1 \cdot 7214 ; 0.10>P>0.05)$.

Table 3 Comparison of numbers of marrow mast cells in serial iliac bone samples before and after renal transplantation

\begin{tabular}{|c|c|c|c|}
\hline Groups compared & $\begin{array}{l}\text { Numbers } \\
\text { of pairs }\end{array}$ & $\mathbf{P}^{*}$ & $\begin{array}{l}\text { Percentage of } \\
\text { cases with } \\
\text { reduced mast } \\
\text { cells }\end{array}$ \\
\hline $\begin{array}{l}\text { Pre-T/Post-T (8-15 mth) } \\
\text { Pre-T/Post-T (20-27 mth) }\end{array}$ & $\begin{array}{l}31 \\
15\end{array}$ & $\begin{array}{l}<0.001 \\
<0.05 \\
>0.02\end{array}$ & $\begin{array}{l}90 \cdot 3 \\
80 \cdot 0\end{array}$ \\
\hline $\begin{array}{l}\text { Post-T (8-15 mth)/ } \\
\text { Post-T (20-27 mth) }\end{array}$ & 15 & $>0.10$ & $26 \cdot 7$ \\
\hline
\end{tabular}

*Wilcoxon's signed rank test for comparison of non-parametric paired samples (Snedecor and Cochran, 1967). Pre-T and Post-T refer to before and after renal transplantation respectively.

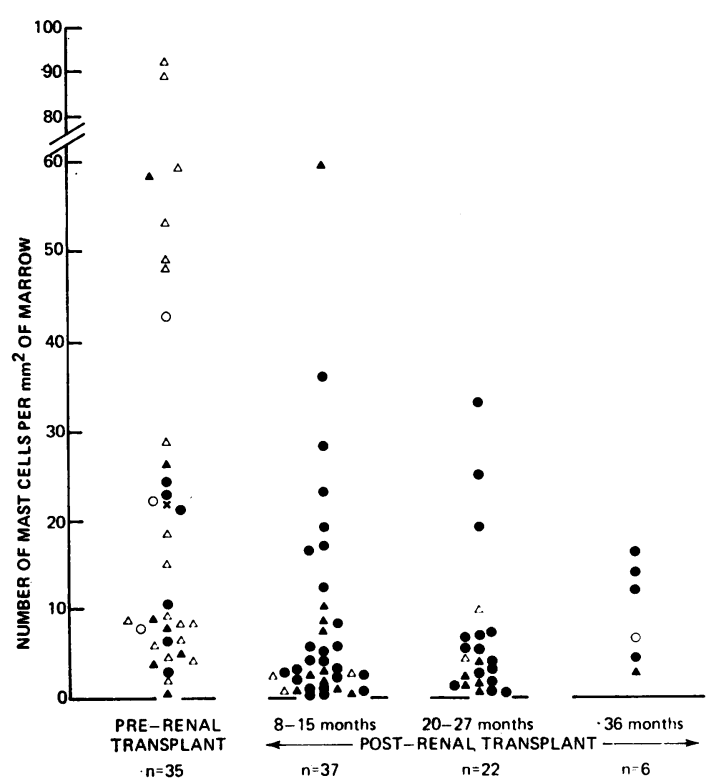

Figure Distribution of numbers of iliac bone marrow mast cells in patients before and after renal transplantation: no osteomalacia, no osteitis fibrosa; O, osteomalacia, no osteitis fibrosa; $\Delta$ osteitis fibrosa, no osteomalacia; $\triangle$ osteomalacia and osteitis fibrosa; $\times$, no undecalcified section available.

After transplantation, histologically moderate to severe osteomalacia resolved in $17(94.4 \%)$ and improved in one $(5.6 \%)$. Two of the three borderline cases of osteomalacia improved but one deteriorated. Of the 20 patients showing improvement of bone mineralisation after transplantation, 
there was a parallel decrease in mast cell numbers in $17(85 \%)$ but, in two, mast cells increased and in one remained unchanged. However, there was a similar fall in mast cell numbers in 13 patients without osteomalacia initially and in one of these osteomalacia had developed after renal transplantation.

RELATIONSHIP BETWEEN NUMBERS OF MAST CELLS AND IMPROVEMENT OF OSTEITIS FIBROSA

Before renal transplantation 26 out of 35 patients $(74.3 \%)$ showed some degree of osteitis fibrosa. There was a progressive reduction in the incidence and in the severity of osteitis fibrosa in many of the patients after transplantation (Table 4). Fluctuations in the numbers of mast cells are apparently not causally related to these changes in osteitis fibrosa. Thus comparison of the pre-transplant and 8-15 month post-transplant data shows a reduction in mast cells in eight patients without osteitis fibrosa before or after transplant and this is of the same order as the reduction observed in 11 patients showing resolution of osteitis fibrosa. Furthermore, osteitis fibrosa became more severe over this period in five patients but the mast cell numbers diminished, and in those three patients with an increase in the number of mast cells there was still an improvement (2) or resolution (1) of osteitis fibrosa.

At 20-27 months serial observations in 16 patients showed a fall in mast cells in five patients with no change in the severity of osteitis fibrosa and a similar fall in mast cells in 8 of 11 patients showing improvement (2) or resolution (9) of osteitis fibrosa.

\section{RELATIONSHIP BETWEEN MAST CELL}

NUMBERS AND RENAL FUNCTION

After renal transplantation renal function improved and serum creatinine values were $<2 \mathrm{mg} / 100 \mathrm{ml}$ in most cases at the time of the post-transplant bone biopsies. There is no significant difference between the ranges of values for marrow mast cell numbers in patients with serum creatinine values $<2 \mathrm{mg} / 100$ $\mathrm{ml}$ or $>2 \mathrm{mg} / 100 \mathrm{ml}$ at any of the three posttransplant periods studied.

Table 4 Percent incidence of various degrees of severity of osteitis fibrosa before and after renal transplantation showing improvement

\begin{tabular}{|c|c|c|c|c|c|}
\hline \multicolumn{2}{|c|}{$\begin{array}{l}\text { Severity of osteitis } \\
\text { fibrosa }\end{array}$} & \multirow{2}{*}{$\begin{array}{l}\text { Pre- } \\
\text { transplant } \\
(\%) \\
(n=35)\end{array}$} & \multicolumn{3}{|c|}{ Post-transplant $(\%)$} \\
\hline Grade & & & $\begin{array}{l}8-15 m t h \\
(n=37)\end{array}$ & $\begin{array}{l}20-27 m t h \\
(n=22)\end{array}$ & $\begin{array}{l}\geqslant 36 m t h \\
(n=6)\end{array}$ \\
\hline $\begin{array}{l}0 \\
1-1 \cdot 5 \\
2-2 \cdot 5 \\
>3\end{array}$ & $\begin{array}{l}\text { Nil } \\
\text { Mild } \\
\text { Moderate } \\
\text { Severe }\end{array}$ & $\begin{array}{r}25 \cdot 7 \\
45 \cdot 7 \\
22 \cdot 9 \\
5 \cdot 7\end{array}$ & $\begin{array}{c}62 \cdot 2 \\
27 \cdot 0 \\
10 \cdot 8 \\
0\end{array}$ & $\begin{array}{c}68 \cdot 2 \\
27 \cdot 3 \\
4 \cdot 5 \\
0\end{array}$ & $\begin{array}{c}83 \cdot 3 \\
16 \cdot 7 \\
0 \\
0\end{array}$ \\
\hline
\end{tabular}

RELATIONSHIP BETWEEN MAST CELL NUMBERS AND STEROID THERAPY

All patients received steroids as part of the immunosuppressive regime after renal transplantation. The total amount of prednisone received by the time the post-transplant bone biopsies were obtained was variable and in particular was dependent upon the occurrence and number of rejection episodes. Examination of the actual doses for each patient reveals no significant relationship between the degree of change in marrow mast cell numbers and the amount of prednisone received.

\section{Discussion}

The increase in number of mast cells which occurs in chronic renal failure is influenced by the events which follow renal transplantation. In many patients the number of mast cells returns to within the normal range. We have previously discussed the possible relationship between marrow mast cells and histological changes of osteitis fibrosa and osteomalacia in azotaemic renal osteodystrophy (Peart and Ellis, 1975; Ellis and Peart, 1976) and the present patients provide a further opportunity to examine this problem since renal transplantation is followed by improvement in both osteitis fibrosa and osteomalacia.

In the case of osteomalacia there is a similar order of reduction in the numbers of marrow mast cells in those patients with osteomalacia initially which improved after transplantation as there is in patients without osteomalacia initially. It seems that resolution of osteomalacia after renal transplantation is not causally related to the reduction in the number of mast cells. The implication is that marrow mast cell hyperplasia and formation of excess osteoid are not related. This is difficult to explain when it is recalled that we previously found an increase in the number of marrow mast cells in patients with osteomalacia due to miscellaneous causes such as malabsorption as well as in haemodialysed patients in whom there was a significant correlation between mast cell numbers and the amount of osteoid present (Ellis and Peart, 1976). Rebel et al. (1974) also noted' increased numbers of mast cells in the marrow of haemodialysed patients and patients with osteomalacia and concluded that an increase in osteoid, whether associated or not with excess resorption of bone, is accompanied by an increase in the number of mast cells and that osteomalacia alone is sufficient to bring this about.

Osteitis fibrosa generally became progressively less severe after renal transplantation. Since mast cells are present in greater numbers in those patients with severe osteitis fibrosa (Peart and Ellis, 1975; 
Ellis and Peart, 1976), it is tempting to relate this improvement in osteitis fibrosa to the fall in mast cell numbers after transplant. Consideration of the data does not support this idea. Thus a fall in the number of mast cells occurred after renal transplantation in patients with or without osteitis fibrosa before operation, and in some patients the osteitis fibrosa became more severe and the mast cell number was still reduced. There is a contrast between the relatively slow manner in which osteitis fibrosa resolves after renal transplantation and the reduction in mast cell numbers which is most marked in the 8 to 15 month samples and later declines or is reversed. Overall there does not seem to be any consistent relationship between changes in the severity of osteitis fibrosa and mast cell numbers after renal transplantation. This is in keeping with our previous failure to relate improvement in osteitis fibrosa and changes in mast cell numbers in patients treated by parathyroidectomy, phosphate binders or vitamin D metabolites (Ellis and Peart, 1976).

One of the notable histological features of bone after successful renal transplantation is that the total amount of bone present is reduced and the often irregular cancellous trabeculae stand out clearly, being invested in a zone of predominantly fatty marrow previously occupied by vascular fibrous tissue as part of the osteitis fibrosa reaction. It is possible that the reduction in marrow mast cell numbers is part of this general replacement of marrow fibrosis by fat since we have previously shown that much of the mast cell increase is located within this particular zone (Peart and Ellis, 1975). Woods and Bishop (1973), in their paper concerned with mast cells and bone resorption, reported that some of the mast cells in the marrow were in close relation to thin-walled vessels which were also increased when osteoporosis appeared to be actively developing. Connective tissue changes of this type cannot be solely responsible for the variations in marrow mast cell numbers, however, since differential cell counts of mast cells in the osteitis fibrosa fibrovascular zone and in the remaining marrow show that in chronic renal failure mast cells are increased in both these sites (Peart and Ellis, 1975).

The present studies of bone changes after renal transplantation have shed no new light on the central problem which is to explain the increase in marrow mast cells in chronic renal failure. The situation is complex since renal transplantation is associated with numerous changes related to the improved renal function of which resolution of osteitis fibrosa and the mineralisation defect form only a part. A further complication is the administration of prednisone in large doses to all these patients with renal transplants. Although we have been unable to relate the precise dose of prednisone to the varying degrees of reduction of mast cell numbers, we cannot exclude the possibility that prednisone may be responsible. The literature is somewhat contradictory regarding the effect of cortisone on tissue mast cell numbers (Selye, 1965). Devitt et al. (1953) were unable to demonstrate any effect of cortisone acetate on mast cell numbers in the rat mesentery, whereas Cavallero and Braccini (1951) found that cortisone reduced the number of mast cells in skin, thigh, muscle, and myocardium, and Asboe-Hansen (1952) refers to reduced mast cell numbers with degranulation in humans and various rodents after treatment with ACTH or cortisone. Fulton et al. (1954) also reported a reduction in the number of mast cells in the hamster mesentery after cortisone treatment.

To summarise our previous (Peart and Ellis, 1975; Ellis and Peart, 1976) and present observations on marrow mast cells in chronic renal failure we can state that (1) the number of mast cells is increased in many patients with chronic renal failure, (2) haemodialysis has no favourable effect on this mast cell increase; (3) although the number of marrow mast cells is greatest in those renal patients with severe degrees of osteitis fibrosa, we have been unable to demonstrate a significant relationship between changes in mast cell numbers and improvement of osteitis fibrosa whether brought about by parathyroidectomy, the use of phosphate binders or vitamin D metabolites, or after renal transplantation; (4) the increase in marrow mast cells is related to the amount of osteoid in haemodialysed patients but this could be a function of the duration of dialysis and not necessarily imply any causal correlation between mast cells and the mineralisation status of bone; (5) marrow mast cells are increased in patients with osteomalacia unassociated with renal disease; (6) after renal transplantation there is a reduction in the number of marrow mast cells but this does not appear to be specifically related to improvement in either osteitis fibrosa or osteomalacia; (7) after renal transplantation changes in marrow cellularity and the administration of prednisone, which may cause a reduction in mast cells, serve further to complicate matters; (8) we are unable to offer any entirely satisfactory explanation for the increase in marrow mast cell numbers which occurs in chronic renal failure.

We acknowledge the help of many of our colleagues in the Department of Medicine, particularly Dr P. R. Uldall and Professor D. N. S. Kerr. We thank Mr H. Elliott for valuable technical assistance and Miss E. D. Davidson for the typescript. KMP and 
AMP were in receipt of a Medical Research Council grant (No. G973/393/C).

\section{References}

Asboe-Hansen, G. (1952). The mast cell. Cortisone action on connective tissue. Proceedings of the Society for Experimental Biology and Medicine, 80, 677-679.

Cavallero, C., and Braccini, C. (1951). Effect of cortisone on the mast cells of the rat. Proceedings of the Society for Experimental Biology and Medicine, 78, 141-143.

Devitt, J. E., Pirozynski, W. J., and Samuels, P. B. (1953). Mast cell resistance to hormonal influence. Proceedings of the Society for Experimental Biology and Medicine, 83, 335-337.

Ellis, H. A., and Peart, K. M. (1972). Quantitative observations on mineralized and non-mineralized bone in the iliac crest. Journal of Clinical Pathology, 25, 277-286

Ellis, H. A., and Peart, K. M. (1973). Azotaemic renal osteodystrophy: a quantitative study on iliac bone. Journal of Clinical Pathology, 26, 83-101.

Ellis, H. A., and Peart, K. M. (1976). Iliac bone marrow mast cells in relation to the renal osteodystrophy of patients treated by haemodialysis. Journal of Clinical Pathology, 29, 502-516.
Fulton, G. P., Maynard, F. L., and West, G. B. (1954). Tissue mast cells in the hamster. Journal of Physiology, 124, 29P-30P.

Peart, K. M., and Ellis, H. A. (1975). Quantitative observations on iliac bone marrow mast cells in chronic renal failure. Journal of Clinical Pathology, 28, 947-955.

Pierides, A. M., Ellis, H. A., Peart, K. M., Simpson, W., Uldall, P. R., and Kerr, D. N. S. (1975). Assessment of renal osteodystrophy following renal transplantation. In Dialysis, Transplantation, Nephrology (Proceedings of the European Dialysis and Transplant Association, vol.11), edited by J. F. Moorhead, R. A. Baillod and C. Mion, pp. 481-487. Pitman, Tunbridge Wells.

Rebel, A., Riberi, P., Bregeon, P., and Malkani, K. (1974). Mastocytes et remaniements du tissu osseux. Pathologie et Biologie, 22, 213-220.

Selye, H. (1965). The Mast Cells. Butterworths, Washington.

Snedecor, G. W., and Cochran, W. G. (1967). Statistical Methods, 6th edition, p. 128. Iowa State University Press, Ames, Iowa.

Woods, C. G., and Bishop, M. (1973). Mast cells and bone resorption-light and electron microscopy of human biopsy material. Proceedings of the Pathological Society of Great Britain and Ireland, Brussels 1973. Pathologie Europaea, 8, 79, (Abstract). 